\title{
(6) OPEN ACCESS \\ Milk feed osmolality and adverse events in newborn infants and animals: a systematic review
}

\author{
Zoë-Marie Ellis, ${ }^{1}$ Hui Shan Grace Tan, ${ }^{1}$ Nicolas D Embleton, ${ }^{2}$ Per Torp Sangild, ${ }^{3,4}$ \\ Ruurd M van Elburg ${ }^{1,5}$
}

Danone Nutricia Research,

Utrecht, The Netherlands

${ }^{2}$ Newcastle Neonatal Service,

Royal Victoria Infirmary,

Newcastle upon Tyne,

Newcastle, UK

${ }^{3}$ Section of Comparative

Pediatrics and Nutrition, Faculty

of Health and Medical Sciences,

University of Copenhagen,

Copenhagen, Denmark

${ }^{4}$ Rigshospitalet, Copenhagen,

Denmark, Department of

Pediatrics and Adolescent

Medicine, Copenhagen,

Denmark

${ }^{5}$ Emma Children's Hospital

Amsterdam University Medical

Centers, Amsterdam, The

Netherlands

\section{Correspondence to}

Professor Ruurd M van Elburg, Danone Nutricia Research, Early Life Nutrition, Uppsalalaan 12, 3584 , The Netherlands: r.m.vanelburg@amc.uva.n

Received 27 July 2018

Revised 12 October 2018 Accepted 5 November 2018

Published Online First

6 December 2018

\begin{abstract}
Background High feed osmolality (or osmolarity)

is often suggested to be linked with adverse

gastrointestinal events in preterm infants.
\end{abstract}

Aim To systematically review the literature on milk feed osmolality and adverse gastrointestinal events in newborn and low birthweight infants and animals.

Methods MEDLINE, Embase, CAB Abstracts, Current Contents, BIOSIS Previews and SciSearch were searched from inception to May 2018 to identify potentially relevant studies. Inclusion criteria: randomised controlled or observational studies of newborn and low birthweight infants or animals investigating the effects of milk-based feeds with different osmolalities. Only full-text, Englishlanguage papers were included.

Results Ten human and six animal studies met the inclusion criteria. Of human studies, seven reported no differences in adverse events with varying feed osmolalities; one reported delayed gastric emptying with feed osmolarity of $539 \mathrm{mOsm} / \mathrm{L}$ compared with lower levels; one reported higher necrotising enterocolitis (NEC) incidence with feed osmolarity of $650 \mathrm{mOsm} / \mathrm{L}$ compared with $359 \mathrm{mOsm} / \mathrm{L}$; one found higher NEC incidence with the lowest feed osmolality (326 mOsm/kg compared with $385 \mathrm{mOsm} / \mathrm{kg}$ ). Of animal studies, two reported delayed gastric emptying with feed osmolarity $>624 \mathrm{mOsm} / \mathrm{L}$, one reported decreased survival due to dehydration with dietary osmolarities $\geq 765 \mathrm{mOsmol} / \mathrm{L}$ and none reported increased NEC incidence with differing feed osmolalities. No clear mechanisms were found, and diet composition differences limited the interpretations regarding the independent impact of osmolality.

Conclusions There is no consistent evidence that differences in feed osmolality in the range 300-500 $\mathrm{mOsm} / \mathrm{kg}$ are associated with adverse gastrointestinal symptoms in neonates.

\section{INTRODUCTION}

Better neonatal care has improved short-term clinical outcomes, including overall survival. However, long-term outcomes, especially neurodevelopment, remain a big concern. ${ }^{1}$ Poor postnatal growth of preterm and low birthweight infants is associated with adverse short-term and long-term clinical outcomes. $^{2}$ Enteral feeding is the cornerstone of nutritional management and growth, but feeding tolerance impacts on the rate of feed advancement. Due to the high nutritional and caloric needs of preterm infants, enteral nutrition of preterm infants, either fortified human milk or preterm formula, has a higher osmolality (or osmolarity) than unfortified human milk. High feed osmolality

\section{Definitions}

- Osmolality: the concentration of a solution in terms of osmoles of solute per kilogram of solvent. Expressed as $\mathrm{mOsm} / \mathrm{kg}$.

- Osmolarity: the concentration of a solution in terms of osmoles of solute per litre of solution. Expressed as $\mathrm{mOsm} / \mathrm{L}$.

is often suggested to be linked with adverse events, particularly gastrointestinal dysfunctions and necrotising enterocolitis (NEC) in preterm infants. The osmolality of mammalian/human milk is approximately $300 \mathrm{mOsm} / \mathrm{kg}^{3}$ but is often increased to levels above $400 \mathrm{mOsm} / \mathrm{kg}$ by addition of human milk fortifiers (HMFs), nutritional supplements and medications. ${ }^{3-5}$ The nutrients that most affect feed osmolality include: monosaccharides and disaccharides, minerals and electrolytes, amino acids, hydrolysed proteins and medium-chain triglycerides. ${ }^{6}$ Recent feeding guidelines for preterm infants do not include an upper recommended level of feed osmolality/osmolarity. ${ }^{7-9}$ The only recommendation is from 1976 by the American Academy of Pediatrics, ${ }^{10}$ which advises that formulas for normal infants should have an osmolarity no greater than $400 \mathrm{mOsm} / \mathrm{L}$ (approximately $450 \mathrm{mOsm} / \mathrm{kg}$ ). As yet, this recommendation remains without clear substantiation based on relevant trials.

In 2013, Pearson et $a l^{11}$ reviewed the subject of feed osmolality and considered the plausibility of osmolality in the causation of NEC, but to date, there has been no systematic review of the literature to examine this area in detail. Therefore, we performed a systematic literature review on human and animal studies to investigate whether there is a link between high milk feed osmolality and adverse gastrointestinal events, including feeding intolerance and NEC. Due to the challenge in performing randomised well-controlled studies on different osmolality diets in humans and the difficulties in assessing underlying mechanisms, we also included animal studies with relevant gastrointestinal endpoints. We included all relevant studies on the topic that measured feed osmolality regardless of differences in formula composition.

\section{MATERIALS AND METHODS}

\section{Search strategy}

Six databases (MEDLINE, Embase, CAB Abstracts, Current Contents, BIOSIS Previews and SciSearch) were searched from inception to 16 May 2018 
to identify potentially relevant studies (online supplementary appendix A). The search yielded a total of 2072 records. Inclusion criteria were: (1) human and animal studies investigating the effects of milk-based and elemental feeds that differ in osmolality/osmolarity; (2) randomised controlled trials (RCT) and observational studies; (3) published full-text articles, (4) for human studies: infants up to 28 days old and (5) for animal studies: outcome measures related to gut function. Exclusion criteria were: (1) non-English records; (2) studies involving medications, vitamin supplements and mineral solutions; (3) studies involving postpyloric feeds; (4) studies not reporting on osmolality/osmolarity levels of feeds; and (5) studies involving infants with other morbidities (eg, hypernatraemia).

\section{Data collection and analysis}

HSGT screened titles and abstracts of the 2072 records and selected potentially relevant records. ZME and HSGT then assessed the abstracts of the selected records for eligibility based on the inclusion and exclusion criteria. Full-text articles of human studies were assessed by four authors (ZME, HSGT, NDE and RMvE) and animal studies by three authors (ZME, HSGT and PTS). Eligibility of each article was based on the prespecified inclusion and exclusion criteria.

\section{Assessment of risk of bias}

Two authors (ZME and HSGT) assessed risk of bias of included studies. Human RCTs were assessed using the criteria of the Cochrane Handbook for Systematic Reviews of Interventions, observational cohort studies were assessed using the Newcastle-Ottawa Quality Assessment Scale for cohort studies and animal studies were assessed using SYRCLE's risk of bias tool for animal intervention studies. ${ }^{12}$ Disagreements were solved after discussion with the other authors (RMvE and NDE for human studies; PTS for animal studies).

\section{Data extraction, management and analysis}

Data were extracted by two authors (ZME and HSGT) using a data collection form. Data extracted included study population characteristics, adverse outcomes, composition of feeds administered and osmolality/osmolarity. Disagreements were solved after discussion with a third author (RMvE). If reported data were insufficient, we contacted authors for further information. No attempt was made to synthesise the data numerically due to variability in osmolality and osmolarity. Findings of the studies were summarised narratively.

\section{RESULTS}

\section{Study selection}

Fifty-eight of the 2072 publications met our inclusion criteria. After reading the full texts, 42 were excluded. Figure 1 shows the Preferred Reporting Items for Systematic Reviews and Meta-Analyses (PRISMA) flow diagram of the search strategy. Of the 10 included human studies, ${ }^{13-22}$ eight were RCTs of which three were cross-over design and two were observational studies (table 1). Table 2 presents details of the six included animal RCT studies. ${ }^{23-28}$ We received additional information from Ramirez et $a l^{14}$ on feed osmolality.

\section{Risk of bias}

Risk of bias of human and animal studies varied and almost all studies had methodological limitations (figures 2 and 3). As reporting of experimental details in animal studies is not yet standard, evaluation of their methodological quality remains

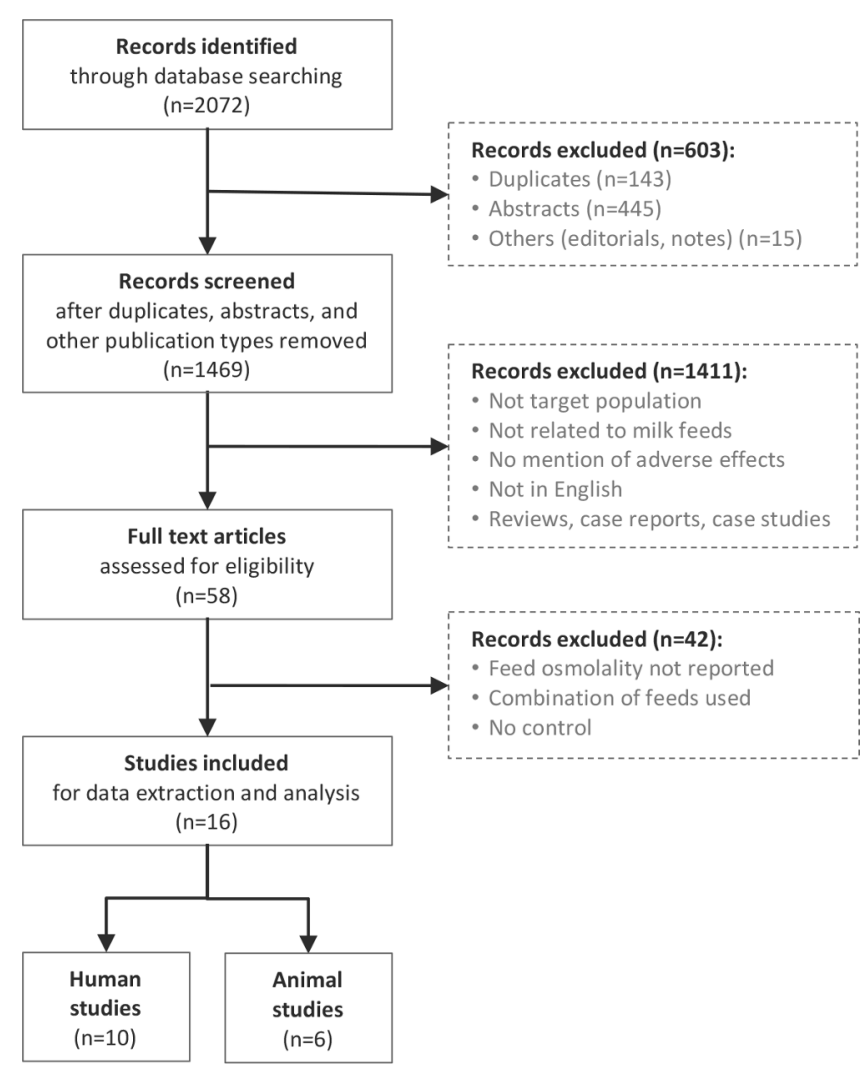

Figure 1 Flow diagram of the literature search process.

difficult. For human RCTs and animal studies, methods of blinding, randomisation and allocation concealment were frequently not clearly described. Incomplete outcome data was judged as having low risk of bias for all studies. For observational studies, high risk of bias was identified for Singh et al ${ }^{19}$ and low risk of bias for Thoene et $a l^{22}$ (online supplementary appendix B).

\section{Human studies}

Gastric emptying

Five studies reported effects of feed osmolality/osmolarity on gastric emptying. ${ }^{13-17}$ In one study, a mean gastric residual of $30 \%$ was found in infants 3 hours after feeding a casein hydrolysate formula $(539 \mathrm{mOsm} / \mathrm{L})$, whereas no gastric residual after feeding an $80 \%$ casein and $20 \%$ soy formula $(204 \mathrm{mOsm} / \mathrm{L})$ and $3.7 \%$ gastric residual with a casein formula $(211 \mathrm{mOsm} / \mathrm{L})$ were found. ${ }^{13}$ Another study found no change in gastric emptying with a feed osmolality of 310 versus $155 \mathrm{mOsm} / \mathrm{kg} .{ }^{14}$ However, gastric emptying was accelerated by decreasing osmolality from 310 to $155 \mathrm{mOsm} / \mathrm{kg}$ while increasing feed volume from $10 \mathrm{~mL} /$ $\mathrm{kg}$ to $20 \mathrm{~mL} / \mathrm{kg}$. Yigit et $a l^{16}$ found no significant difference in gastric residuals after feeding different feeds with an osmolarity ranging from $275 \mathrm{mOsm} / \mathrm{L}$ to $576 \mathrm{mOsm} / \mathrm{L}$. Similarly, Siegel et $a l^{15}$ reported no significant difference in gastric emptying between feeding a soybean formula containing sucrose (279 $\mathrm{mOsm} / \mathrm{kg}$ ) or containing glucose $(448 \mathrm{mOsm} / \mathrm{kg})$. Kanmaz et $a l^{17}$ also reported no significant difference in gastric residuals after feedings with osmolarities ranging from $340 \mathrm{mOsm} / \mathrm{L}$ to $380 \mathrm{mOsm} / \mathrm{L}$.

\section{Feeding intolerance}

Four studies assessed the influence of dietary osmolality/ osmolarity on feeding tolerance. ${ }^{17-20}$ The definition of feeding 


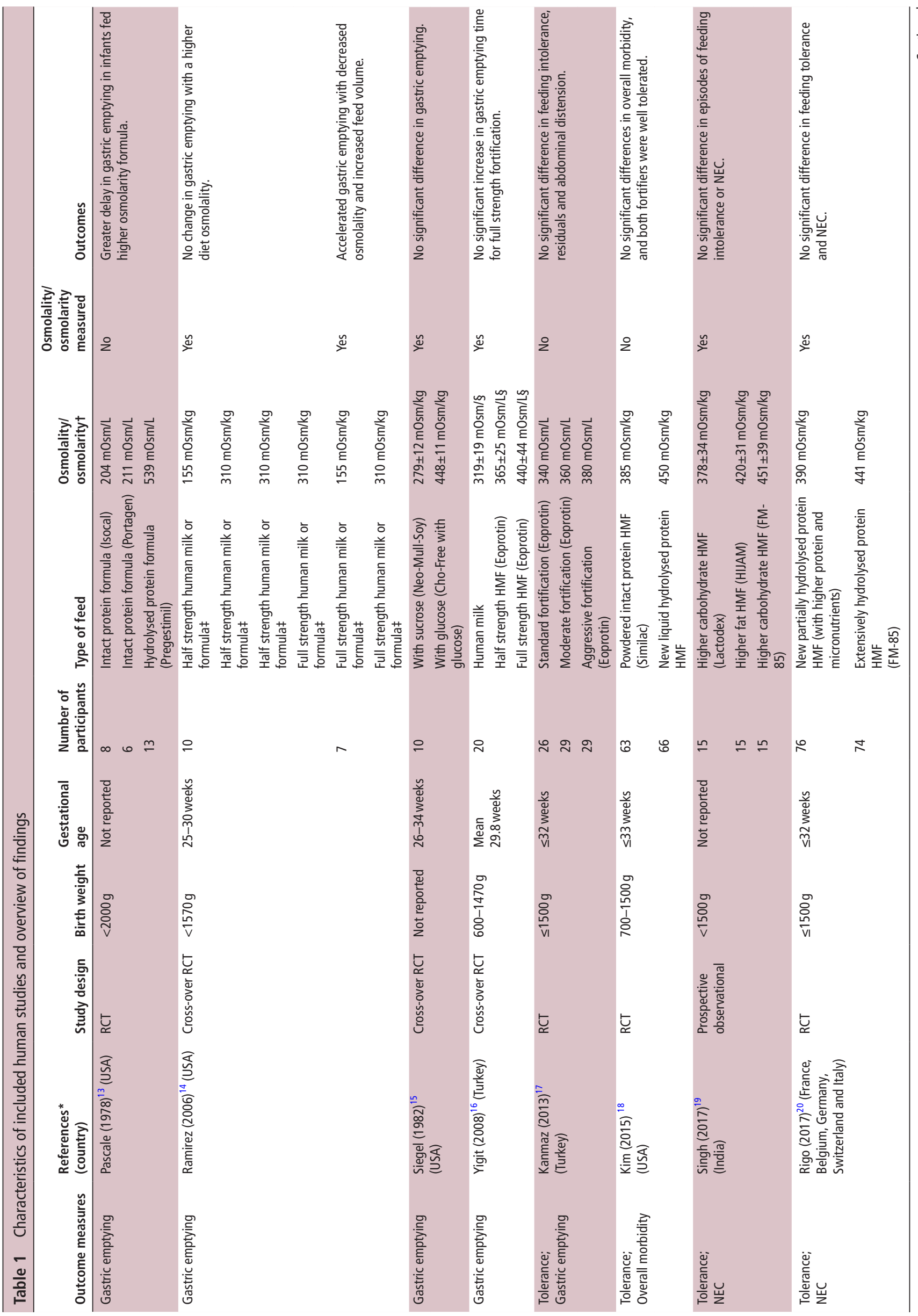


intolerance varied among the studies but frequently included presence of abdominal distension, vomiting and delayed/withheld feedings. None of these studies found significant differences in feeding tolerance with feed osmolalities up to $451 \mathrm{mOsm} /$ kg. ${ }^{17-20}$

\section{NEC and overall morbidity}

Five studies reported the effects of dietary osmolality/osmolarity on NEC and overall morbidity. ${ }^{18-22}$ One study reported a significantly higher NEC incidence in infants after receiving an elemental formula $(650 \mathrm{mOsm} / \mathrm{L})$ compared with a cow milkbased formula $(359 \mathrm{mOsm} / \mathrm{L})(87.5 \%$ vs $25 \%$, respectively; $\mathrm{p}<0.02) .{ }^{21}$ Thoene et $a l^{22}$ reported a significantly higher NEC incidence in infants receiving an acidified liquid HMF (326 $\mathrm{mOsm} / \mathrm{kg}$ ) compared with those receiving a powdered HMF (385 mOsm $/ \mathrm{kg}$ ) and a non-acidified liquid HMF $(385 \mathrm{mOsm} /$ $\mathrm{kg})(13 \%, 0 \%$ and $0 \%$, respectively; $\mathrm{p}=0.0056)$. Rigo et $a l^{20}$ found no significant difference in NEC incidence comparing one HMF (441 mOsm $/ \mathrm{kg}$ ) with a new HMF with higher protein and micronutrient content $(390 \mathrm{mOsm} / \mathrm{kg})$. Similarly, Singh et al ${ }^{19}$ found no significant difference in NEC incidence with different feed osmolalities $(451 \mathrm{mOsm} / \mathrm{kg}, 420 \mathrm{mOsm} / \mathrm{kg}$ and $378 \mathrm{mOsm} /$ $\mathrm{kg})$. Furthermore, Kim et $a l^{18}$ reported no significant difference in overall morbidity (NEC and sepsis) in infants fed either a liquid HMF (450 mOsm/kg) or a powder HMF (385 mOsm/kg).

\section{Animal studies}

Adverse events and paraclinical endpoints

Six studies evaluated the mechanistic effects of feeds with different osmolalities/osmolarities, ${ }^{23-28}$ although not necessarily the main aim of these studies. Goldblum et $a l^{23}$ found no significant difference in intestinal luminal osmolality of the proximal and distal intestine after feeding neonatal dogs with a hyperosmolar feed $(710 \mathrm{mOsm} / \mathrm{kg})$ compared with iso-osmolar feeds. Gastric content could only be recovered in the group fed hyperosmolar feed, implying delayed gastric emptying. Similarly, Miller $e t a l^{24}$ found prolonged gastric emptying time and increased water in the intestine in neonatal rats with increased dietary osmolality. ${ }^{24}$ Miyake et $a l^{25}$ reported similar mucosal injury scores in neonatal mice in two NEC-induced groups fed hyperosmolar feeds and both had higher scores than a control human milk fed group. Szabo and Fewell ${ }^{27}$ and Szabo et $a l^{28}$ concluded that a single hyperosmolar feed did not induce intestinal motor dysfunction, differences in gastrointestinal hormone concentration, bacterial proliferation or intestinal mucosal damage in neonatal piglets. In preterm piglets, Sun et $a l^{26}$ found no differences in gut permeability after feeding human milk with different fortification, resulting in osmolalities from 289 $\mathrm{mOsm} / \mathrm{kg}$ to $460 \mathrm{mOsm} / \mathrm{kg}$. However, differences were found in several structural, functional and immune parameters in the intestine and blood in the group receiving human milk with a formula-based fortifier (460 $\mathrm{mOsm} / \mathrm{kg}$ ) compared with those receiving human milk with bovine colostrum $(408 \mathrm{mOsm} / \mathrm{kg})$. Gastric residuals were also significantly higher in this group compared with groups fed donor human milk with or without fortifier $(\mathrm{p}<0.05)$.

Three studies evaluated the effects of a hyperosmolar feed on clinical outcomes. ${ }^{24-26}$ Miller and Czajka ${ }^{24}$ reported decreased survival in neonatal rats after feeds with a dietary osmolarity $\geq 765 \mathrm{mOsmol} / \mathrm{L}$. In a mice study by Miyake et al, ${ }^{25} \mathrm{NEC}$ was induced by giving hypoxia and gavage administration of lipopolysaccharide and formula feeding. NEC incidence was similar in groups that received a lower $(325 \mathrm{mOsm} / \mathrm{kg})$ versus 


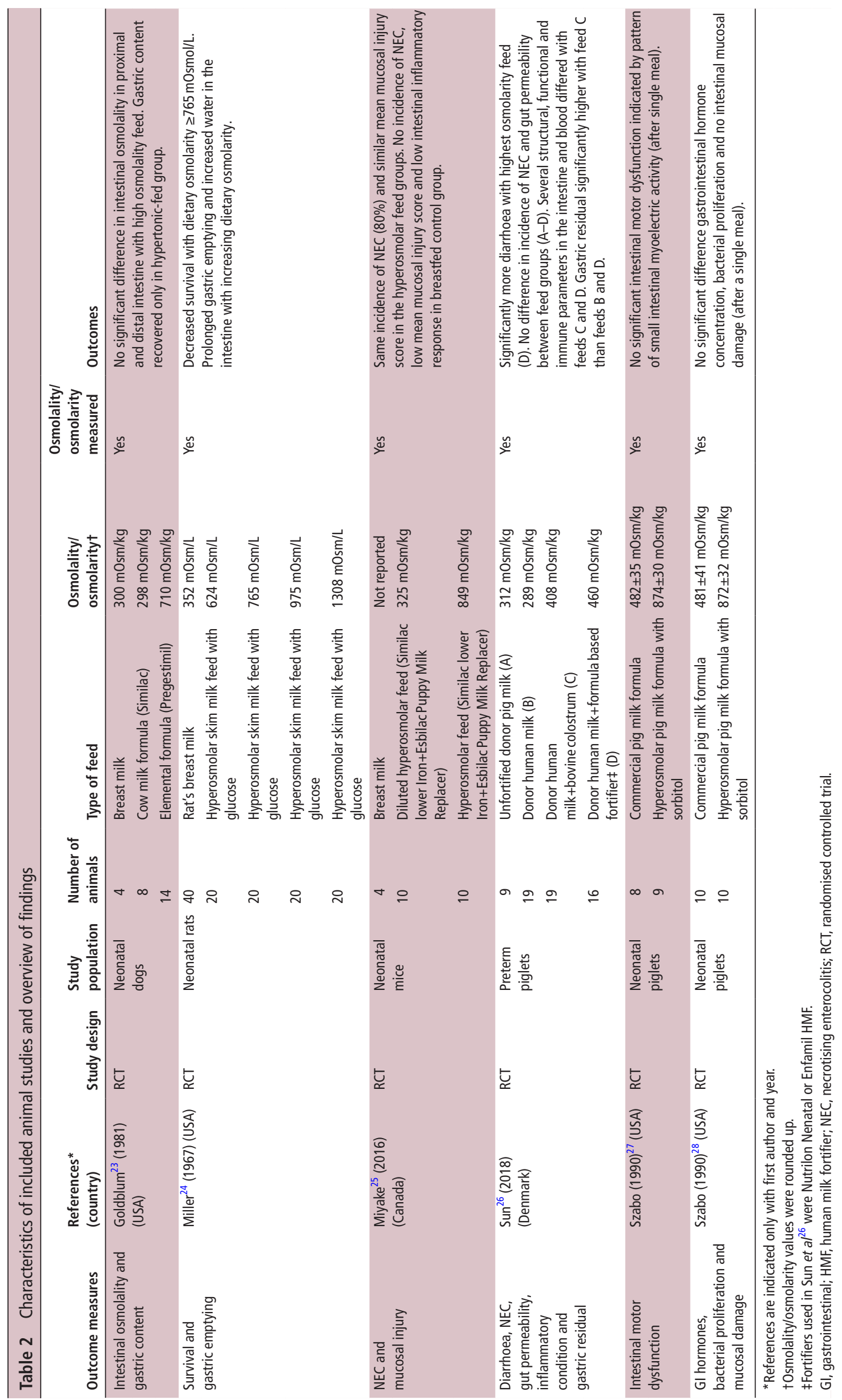



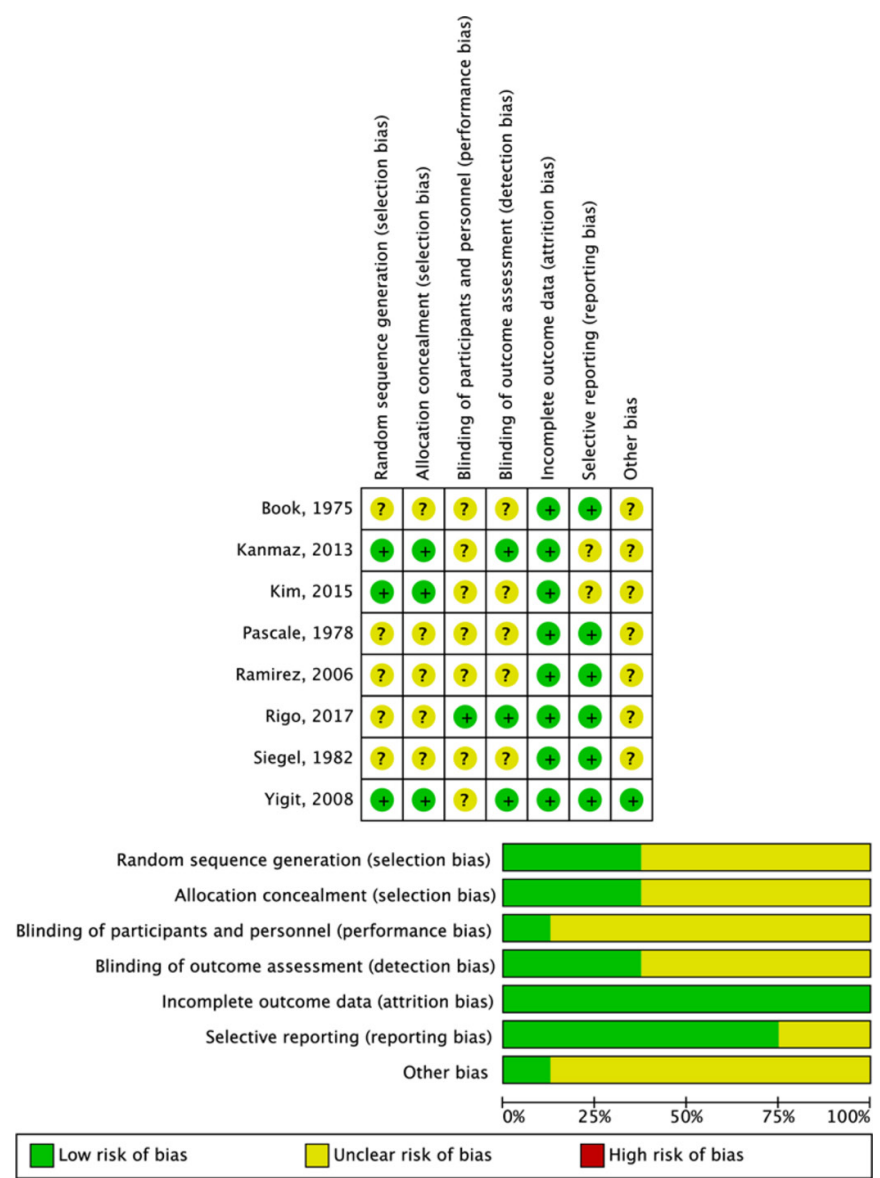

Figure 2 Assessment of the risk of bias in included human randomised controlled trials and the review authors' judgements about each risk of bias item presented as percentages.

higher $(849 \mathrm{mOsm} / \mathrm{kg})$ osmolality feed. There were no NEC cases in the control breastmilk fed group without lipopolysaccharide or hypoxia. Sun $e t a l^{26}$ found significantly more diarrhoea in preterm piglets fed donor human milk with a formula-based fortifier $(460 \mathrm{mOsm} / \mathrm{kg}$ ) compared with groups receiving unfortified donor human, sow's milk or donor human milk with bovine colostrum $(312-408 \mathrm{mOsm} / \mathrm{kg})(\mathrm{p}<0.05)$. There was no significant difference in NEC incidence between the groups receiving different feed osmolalities (289-460 mOsm/kg).

\section{DISCUSSION}

Based on the 10 included human studies with 618 infants, we found no consistent evidence that feed osmolality/osmolarity is associated with any adverse gastrointestinal events especially feeding intolerance, except at very high levels (eg, $>539 \mathrm{mOsm} / \mathrm{L})$. Below this level, we found no difference in feeding intolerance when infants were fed differing feed osmolalities (up to $450 \mathrm{mOsm} / \mathrm{kg}$ ). As delayed gastric emptying is often regarded a major determinant of feed intolerance, we expected similar results for this outcome, and indeed we found no changes in gastric emptying with differing feed osmolarities (up to $440 \mathrm{mOsm} / \mathrm{L}$ ). Only one human study ${ }^{13}$ found a greater delay in gastric emptying with a feed osmolarity of 539 $\mathrm{mOsm} / \mathrm{L}$. However, significant differences in protein, fat and carbohydrate composition, besides differences in feed osmolarities in the studied formula, limit the interpretation of this result. Siegel et $a l^{15}$ subsequently performed a study where similar feed compositions were used and found that feed osmolality did

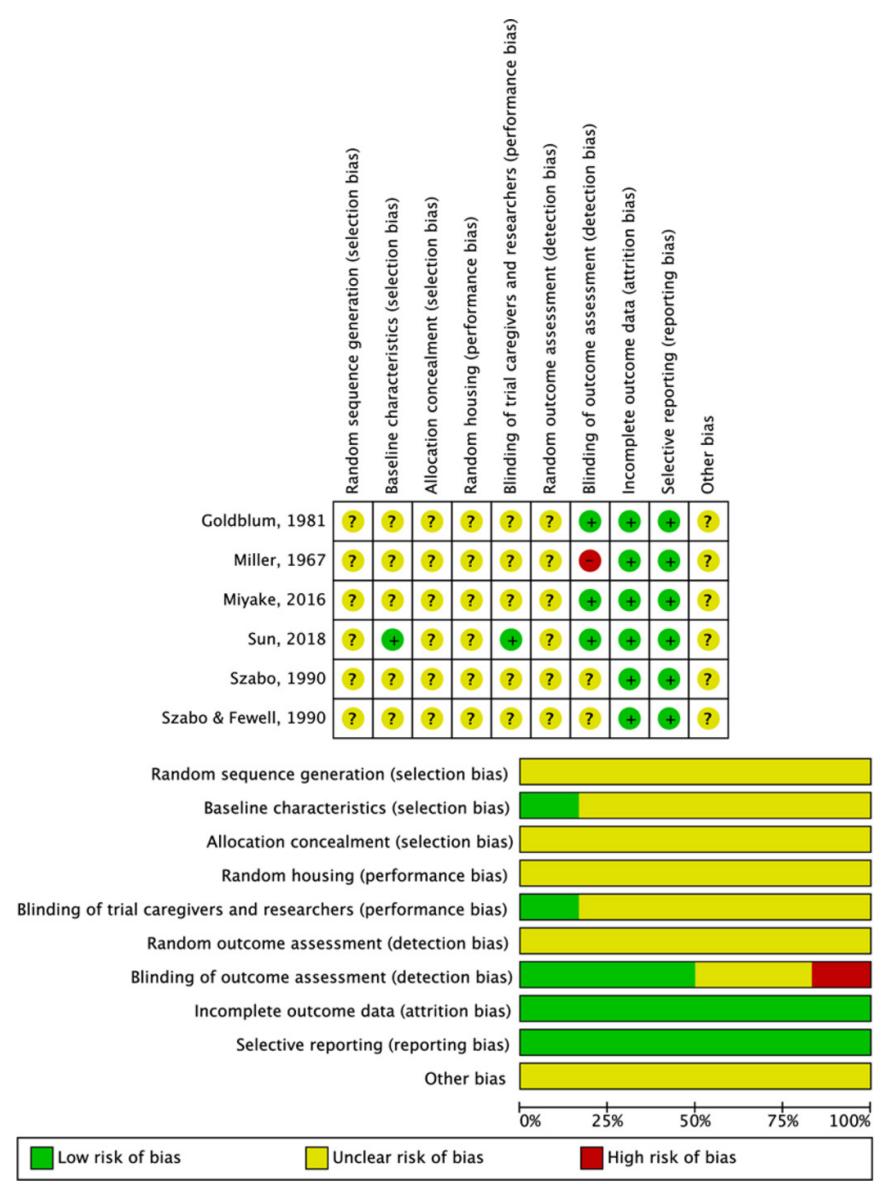

Figure 3 Assessment of the risk of bias in included animal studies and the review authors' judgements about each risk of bias item presented as percentages.

not significantly influence gastric emptying. However, the feed osmolalities tested in this study (up to $448 \mathrm{mOsm} / \mathrm{kg}$ ) were much lower than in the study by Pascale et al. ${ }^{13}$

In comparison, some animal studies found that increasing feed osmolarities $>624 \mathrm{mOsm} / \mathrm{L}$, regardless of feed composition, delayed gastric emptying. ${ }^{23} 24$ The exact mechanisms for delayed gastric emptying are not clear from these studies. However, Goldblum et $a^{23}$ reported a reduction in osmolarity in the contents of the proximal intestine in neonatal dogs after a hyperosmolar feed, indicating dilution occurring in the stomach. This dilution may have occurred through osmoreceptors in the duodenum initiating a delay in gastric emptying through direct interactions with the stomach. ${ }^{29}$ In preterm piglets, ${ }^{26}$ higher gastric residuals were found in piglets fed with an osmolality of $408 \mathrm{mOsm} / \mathrm{kg}$ compared with an osmolality of $460 \mathrm{mOsm} / \mathrm{kg}$; however, the feed compositions in this study differed markedly (different fortifiers to human donor milk).

In a study published after our literature search was completed, ${ }^{30}$ three fortifiers with varying feed osmolalities $(320 \mathrm{mOsm} / \mathrm{kg}$, $379 \mathrm{mOsm} / \mathrm{kg}$ and $498 \mathrm{mOsm} / \mathrm{kg}$ ) added to human donor milk fed to preterm piglets were compared. Gastric residuals were similar among groups, but NEC incidence and gut inflammatory reactions were highest in the group fed fortified human milk with the highest osmolality. Furthermore, in another recently published piglet study by one of the authors (PTS), ${ }^{31}$ a free amino acid-based formula diet showed adverse effects on digestion and growth compared with three diets consisting of $70 \%$ intact proteins and 30\% essential amino acids. This effect 
could have been due to the higher osmolality in the free amino acids groups compared with the other groups $(580 \mathrm{mOsm} / \mathrm{kg}$ vs $470-480 \mathrm{mOsm} / \mathrm{kg}$, measured but not described in the paper). Together, the results of the animal and human studies raise the question whether there is a certain level of feed osmolality where diets start to delay gastric emptying and create adverse intestinal reactions. However, it is important to acknowledge that most studies did not have osmolality/osmolarity as the principal dietary factor that varied and many other nutritional components (eg, fat, protein, calcium, magnesium and phosphate) varied between the diet groups, which may influence outcomes.

The most severe clinical manifestation of feeding intolerance in neonates is NEC. We found no evidence in human studies that milk feed osmolalities (up to $450 \mathrm{mOsm} / \mathrm{kg}$ ) increased the incidence of NEC. Only one small human study found a significantly higher NEC incidence with a feed osmolarity of $650 \mathrm{mOsm} / \mathrm{L}{ }^{21}$ However, significant differences in formulae compositions make it impossible to determine whether the higher NEC incidence was directly attributed to the high feed osmolarity or due to the specific formula composition (i.e. casein hydrolysate with high medium-chain triglycerides and glucose content) or a combination of both. The specific role of formula composition is illustrated by Thoene $e t a l,{ }^{22}$ reporting a higher NEC incidence in infants fed an acidified HMF with the lowest feed osmolality $(326 \mathrm{mOsm} / \mathrm{kg})$. In the animal studies, we found no significant difference in the incidence of NEC with differing feed osmolalities (up to $849 \mathrm{mOsm} / \mathrm{kg}$ ). NEC was induced in neonatal mice by Miyake $e t a^{25}$ through gavage formula feeding (regardless of osmolality) combined with lipopolysaccharides and hypoxia. This is a method frequently adopted by others in rodents, ${ }^{32} 33$ suggesting that other factors than solely feed osmolality play a role in the development of NEC, at least in rodents. In piglets, however, infant formula feeding alone can induce spontaneous NEC-like symptoms without exposure to hypoxia, gavage and lipopolysaccharide. ${ }^{34}$ Lower osmolality diets, such as unfortified human, bovine or porcine milk or colostrum, clearly result in lower NEC sensitivity and less adverse intestinal reactions than formula in preterm piglets. ${ }^{2635-38}$ However, it remains unclear if this is due to lower feed osmolality or to composition of nutrients and protective bioactive factors in natural milk diets.

Besides adverse gastrointestinal events, neonatal rats fed a diet $\geq 765 \mathrm{mOsmol} / \mathrm{L}$ had increased mortality due to dehydration. ${ }^{24}$ Compared with adult rats, newborn rats have reduced kidney function and difficulty conserving water in the body. ${ }^{24}$ The impaired ability to maintain fluid homeostasis coupled with hyperosmolar feeds may lead to severe dehydration. Although it is inappropriate to directly extrapolate the results of this animal study to humans, neonatal infants also have reduced kidney function and difficulty regulating fluid balance increasing the risk of overhydration and dehydration, ${ }^{40}$ thus feeds with a very high osmolality may also have other adverse effects in preterm infants.

\section{Strengths and weaknesses of the review}

To our knowledge, this is the first systematic review to investigate the link between feed osmolality and adverse gastrointestinal events. The strength of this review is the systematic approach of searching the literature with no restriction to year of publication and selection of studies based on prespecified inclusion and exclusion criteria. The PRISMA checklist was used to assist with the reporting of the review (online supplementary appendix C). Each full-text article was reviewed by three or more researchers independently. The limitations of this review include that only one reviewer screened the titles and abstracts of all search records and excluded obvious ineligible studies. The remainder were reviewed by at least two reviewers to select all eligible studies for inclusion. Furthermore, we restricted the review to only include studies published as full-text articles in English and that reported on osmolality/osmolarity. The included studies varied in methodological quality, mainly limited by unclear blinding, and no or unclear randomisation and allocation concealment. Feed osmolarity, when measured, was frequently highly variable and in some studies not measured but assumed, limiting the interpretation of any cut-off values that could influence outcomes. Although we acknowledge that it is necessary to alter at least one aspect of a feed to change the osmolality/osmolarity, significant differences in formula composition in the studies make it difficult to evaluate the independent effect of feed osmolality/osmolarity on specific adverse outcomes. An additional limitation was the relatively small number of neonates in each study included in this review, limiting the interpretation of the results. The interpretation of animal studies may be limited as the actual level by which osmolality adversely affects the infant versus animal intestine could differ; however, findings from the animal studies support the findings in human studies. Future RCTs would need to enrol $>1000$ infants to be powered to determine effects on key morbidities such as NEC or sepsis. It will remain difficult to investigate the specific effect of feed osmolality, independently of associated changes in dietary ingredients. Well-designed animal studies, using serial dilutions of osmolality, may help to identify mechanisms related to adverse gastrointestinal and metabolic effects of hyperosmolar diets. Until further scientific evidence is available, an upper maximum for osmolality/osmolarity in milk diets, especially for vulnerable groups such as preterm infants, are based on the pragmatic conclusions from existing infant and animal studies.

\section{CONCLUSIONS}

In conclusion, we found no consistent evidence that feed osmolality of $300-500 \mathrm{mOsm} / \mathrm{kg}$ poses a safety risk to newborn infants. In the available studies, significant differences in feed composition among diets with different osmolality levels limit the interpretation of results regarding the independent impact of osmolality.

Contributors Z-ME and RMvE designed the research, which was conducted by Z-ME and HSGT in terms of search of papers, paper selection (final selection together with RMvE, NDE and PTS) and figure generation. All authors contributed equally to manuscript writing and take equal responsibility for final content.

Funding The authors have not declared a specific grant for this research from any funding agency in the public, commercial or not-for-profit sectors.

Competing interests Z-ME, HSGT and RMvE are employees of Danone Nutricia Research, Utrecht, The Netherlands. NDE has previously conducted research with support from manufacturers of infant formula including Nestec SA (Switzerland), Wyeth UK and Nutricia UK but did not receive any payment, support or benefit in kind for contribution to this manuscript and has no ongoing personal, consultancy or financial relationships with Nutricia or other relevant commercial interest. PTS has nothing to declare.

Patient consent Not required.

Provenance and peer review Not commissioned; externally peer reviewed.

Open access This is an open access article distributed in accordance with the Creative Commons Attribution Non Commercial (CC BY-NC 4.0) license, which permits others to distribute, remix, adapt, build upon this work non-commercially, and license their derivative works on different terms, provided the original work is properly cited, appropriate credit is given, any changes made indicated, and the use is non-commercial. See: http://creativecommons.org/licenses/by-nc/4.0/.

\section{REFERENCES}

1 Twilhaar ES, Wade RM, de Kieviet JF, et al. Cognitive outcomes of children born extremely or very preterm since the 1990 s and associated risk factors: a meta-analysis and meta-regression. JAMA Pediatr 2018;172:361-7. 
2 Ong KK, Kennedy K, Castañeda-Gutiérrez E, et al. Postnatal growth in preterm infants and later health outcomes: a systematic review. Acta Paediatr 2015;104:974-86.

3 Rochow N, Fusch G, Choi A, et al. Target fortification of breast milk with fat, protein, and carbohydrates for preterm infants. J Pediatr 2013;163:1001-7.

4 Chandran S, Chua MC, Lin W, et al. Medications that increase osmolality and compromise the safety of enteral feeding in preterm infants. Neonatology 2017;111:309-16.

5 Srinivasan L, Bokiniec R, King C, et al. Increased osmolality of breast milk with therapeutic additives. Arch Dis Child Fetal Neonatal Ed 2004;89:F514-7.

6 Waitzberg DL, Torrinhas RS. Enteral feeding. Encyclopedia of Food and Health 2016:519-23.

7 Agostoni C, Buonocore G, Carnielli VP, et al. Enteral nutrient supply for preterm infants: commentary from the European Society of Paediatric Gastroenterology, Hepatology and Nutrition Committee on Nutrition. J Pediatr Gastroenterol Nutr 2010:50:85-91.

8 Koletzko B, Poindexter B, Uauy R. Recommended nutrient intake levels for stable, fully enterally fed very low birth weight infants. In: Koletzko B, Poindexter B, Uauy R, eds. Nutritional care of preterm infants. Basel: Karger, 2014:297-9.

9 AAP. American academy of pediatrics: Nutritional needs for the preterm infant. In: Kleinman RE, Greer FR, eds. Pediatric nutrition. Elk grove village: IL: American Academy of Pediatrics, 2014:83-110.

10 Barness LA, Mauer AM, Holliday MA, et al. Commentary on breast-feeding and infant formulas, including proposed standards for formulas. Pediatrics 1976;57:278-85.

11 Pearson F, Johnson MJ, Leaf AA. Milk osmolality: does it matter? Arch Dis Child Fetal Neonatal Ed 2013;98:F166-F169.

12 Hooijmans CR, Rovers MM, de Vries RB, et al. SYRCLE's risk of bias tool for anima studies. BMC Med Res Methodol 2014;14:43.

13 Pascale JA, Mims LC, Greenberg MG, et al. Gastric response in low birth weight infants fed various formulas. Biol Neonate 1978;34:150-4.

14 Ramirez A, Wong WW, Shulman RJ, et al. Factors regulating gastric emptying in preterm infants. J Pediatr 2006;149:475-9.

15 Siegel M, Lebenthal E, Topper W, et al. Gastric emptying in prematures of isocaloric feedings with differing osmolalities. Pediatr Res 1982;16:141-7.

16 Yigit S, Akgoz A, Memisoglu A, et al. Breast milk fortification: effect on gastric emptying. J Matern Fetal Neonatal Med 2008;21:843-6.

17 Kanmaz HG, Mutlu B, Canpolat FE, et al. Human milk fortification with differing amounts of fortifier and its association with growth and metabolic responses in preterm infants. J Hum Lact 2013;29:400-5.

$18 \mathrm{Kim} \mathrm{JH}$, Chan G, Schanler R, et al. Growth and Tolerance of Preterm Infants Fed a New Extensively Hydrolyzed Liquid Human Milk Fortifier. J Pediatr Gastroenterol Nutr 2015;61:665-71.

19 Singh P, Thakur A, Dogra S, et al. Comparison of osmolality of human milk after fortification with three different fortifiers. Current Medicine Research and Practice 2017:7:81-3.

20 Rigo J, Hascoët JM, Billeaud C, et al. Growth and nutritional biomarkers of preterm infants fed a new powdered human milk fortifier: a randomized trial. J Pediatr Gastroenterol Nutr 2017;65:e83-e93.

21 Book LS, Herbst JJ, Atherton SO, et al. Necrotizing enterocolitis in low-birth-weight infants fed an elemental formula. J Pediatr 1975;87:602-5.
22 Thoene M, Lyden E, Weishaar K, et al. comparison of a powdered, acidified liquid, and non-acidified liquid human milk fortifier on clinical outcomes in premature infants. Nutrients 2016:8:451.

23 Goldblum OM, Holzman IR, Fisher SE. Intragastric feeding in the neonatal dog. Its effect on intestinal osmolality. Am J Dis Child 1981;135:631-3.

24 Miller SA, Czajka DM. The influence of dietary osmolarity on survival in the neonatal rat. Biol Neonat 1967;11:197-203.

25 Miyake $\mathrm{H}$, Chen Y, Koike Y, et al. Osmolality of enteral formula and severity of experimental necrotizing enterocolitis. Pediatr Surg Int 2016;32:1153-6.

26 Sun J, Li Y, Nguyen DN, et al. Nutrient Fortification of Human Donor Milk Affects Intestinal Function and Protein Metabolism in Preterm Pigs. J Nutr 2018;148:336-47.

27 Szabo JS, Fewell JE. Small intestinal myoelectric activity in healthy neonatal piglets: effects of hyperosmolal formula. J Pediatr Gastroenterol Nutr 1990;11:101-8.

28 Szabo JS, Rayford PL, Uthman E, et al. Hyperosmolal formula in neonatal piglets: effects on gastrointestinal hormone concentrations, enteric bacterial titers, and small intestinal histology. J Pediatr Gastroenterol Nutr 1990;11:109-14.

29 Lin HC, Elashoff JD, Gu YG, et al. Nutrient feedback inhibition of gastric emptying plays a larger role than osmotically dependent duodenal resistance. Am J Physiol 1993:265:G672-G676.

30 Sun J, Li Y, Pan X, et al. Human milk fortification with bovine colostrum is superior to formula-based fortifiers to prevent gut dysfunction, necrotizing enterocolitis, and systemic infection in preterm pigs. JPEN J Parenter Enteral Nutr 2018.

31 Worsøe PS, Sangild PT, van Goudoever JB, et al. growth and clinical variables in nitrogen-restricted piglets fed an adjusted essential amino acid mix: effects of partially intact protein-based diets. J Nutr 2018;148:1118-1125.

32 Zani A, Zani-Ruttenstock E, Peyvandi $F$, et al. A spectrum of intestinal injury models in neonatal mice. Pediatr Surg Int 2016;32:65-70.

33 Koike $Y$, Li B, Lee $C$, et al. Gastric emptying is reduced in experimental NEC and correlates with the severity of intestinal damage. J Pediatr Surg 2017;52:744-8.

34 Sangild PT, Siggers RH, Schmidt M, et al. Diet- and colonization-dependent intestinal dysfunction predisposes to necrotizing enterocolitis in preterm pigs. Gastroenterology 2006;130:1776-92.

35 Jensen ML, Sangild PT, Lykke M, et al. Similar efficacy of human banked milk and bovine colostrum to decrease incidence of necrotizing enterocolitis in preterm piglets. Am J Physiol Regul Integr Comp Physiol 2013;305:R4-R12.

36 Bjornvad CR, Thymann T, Deutz NE, et al. Enteral feeding induces diet-dependent mucosal dysfunction, bacterial proliferation, and necrotizing enterocolitis in preterm pigs on parenteral nutrition. Am J Physiol Gastrointest Liver Physiol 2008;295:G1092.

37 Rasmussen SO, Martin L, Østergaard MV, et al. Bovine colostrum improves neonatal growth, digestive function, and gut immunity relative to donor human milk and infant formula in preterm pigs. Am J Physiol Gastrointest Liver Physiol 2016:311:G480

38 Li Y, Jensen ML, Chatterton DE, et al. Raw bovine milk improves gut responses to feeding relative to infant formula in preterm piglets. Am J Physiol Gastrointest Liver Physiol 2014;306:G81-G90.

39 ADOLPH EF. Ontogeny of physiological regulations in the rat. Q Rev Biol 1957:32:89-137.

40 Blackburn ST. Renal function in the neonate. J Perinat Neonatal Nurs 1994;8:37-47. 